\title{
Why Christians Should Not Be Kaneans about Freedom
}

\author{
Michael D. Bertrand \\ Department of Philosophy \\ Auburn University \\ Auburn, Alabama \\ mdb0068@auburn.edu \\ JACK MuldeR, JR. \\ Department of Philosophy \\ Hope College \\ Holland, Michigan \\ mulderj@hope.edu
}

Even our Lord in His Passion shrank with an unspeakable horror and a mortal loathing from the pains of death. He says so Himself, but with the fine point of His spirit, He was resigned to the will of His Father. All the rest was only the struggle of nature.

St. Francis de Sales

This is all paradoxical in the highest degree: we stand here before a conflict that wants itself to be conflicted....

Friedrich Nietzsche

This paper argues that a prominent theory of libertarian freedom, namely, Robert Kane's, is unable to accommodate the moral psychology of a sinless individual whose decisions have, at some point, been morally significant. This is because a sinless agent cannot voluntarily accord value to an immoral desire, and we argue that Kane's theory requires this. Why is this important? Because the historic Christian faith generally teaches that Jesus is sinless, and, if they are to be consistent, Christians need a theory of free action that takes Jesus himself into account. ${ }^{1}$ Although Jesus is usually

ABSTRACT: In this paper we argue that Robert Kane's theory of free will cannot accommodate the possibility of a sinless individual who faces morally significant choices because a sinless agent cannot voluntarily accord value to an immoral desire, and we argue that Kane's theory requires this. Since the Jesus of the historic Christian tradition is held to be sinless, we think Christians should reject Kane's theory because it seems irreconcilable with historic Christian Christology. We consider two objections to our argument and argue that both fail.

1. Indeed, Orthodox and Catholic Christians also hold the Virgin Mary is sinless, though there are differences in their views. Consider, for instance, Jack Mulder, Jr., What Does It Mean to Be Catholic? (Grand Rapids, MI: Eerdmans, 2015), ch. 5, and Timothy (Kallistos) Ware, 
thought to possess perfect virtue, sinlessness as a state need not be identical to perfect virtue, which could be won through a long period of struggle. For our purposes in this paper, sinlessness should be understood simply as a lack of blameworthiness for particular acts during one's lifetime.

Kane's theory of libertarian freedom (hereafter KL for "Kanean Libertarianism") is widely thought to be attractive because it offers an account of incompatibilist freedom that does not require substance dualism, or Roderick Chisholm's "prime mover unmoved." Indeed, after detailing what he calls the "theory of agency" model of freedom that avoids determinism and avoids relying on quantum indeterminacy, Richard Taylor writes, "One can hardly affirm such a theory of agency with complete comfort, however, and not wholly without embarrassment, for the conception of agents and their powers which is involved in it is strange indeed, if not positively mysterious. ${ }^{\prime 3}$ Kane espouses a variety of event causation that locates indeterminism in the brain and that, he hopes, will avoid appeals to mystery and the embarrassment Taylor cites. As Kane writes, "The idea [behind his view of free will] was to put aside traditional libertarian appeals to special forms of agency or causation that in the past have evoked charges of mystery or obscurity and seem to have no place in the natural order in which we must exercise our free will." ${ }^{\prime 4}$

How does he attempt to locate free will in this natural order? Kane writes,

There is a tension and uncertainty in our minds at such times of inner conflict that is reflected in appropriate regions of our brains by movement away from thermodynamic equilibrium - in short, a kind of stirring up of chaos in the brain that makes it sensitive to micro-indeterminacies at the neuronal level. As a result, the uncertainty and inner tension we feel at such soul-searching moments of self-formation is reflected in the indeterminacy of our neural processes themselves. ${ }^{5}$

Accordingly, KL holds that moments of morally significant conflict reflect the indeterminacy generated by "connected neural networks" in the brain.

One of Kane's common examples features a businesswoman we will call "Anne" who, while on her way to an important meeting, sees a person

The Orthodox Church, new ed. (London: Penguin, 1997), 257-60, for some information on this topic.

2. See Roderick Chisholm, "Human Freedom and the Self," in Laura Waddell Ekstrom, ed., Agency and Responsibility: Essays in the Metaphysics of Freedom (Boulder, CO: Westview, 2001), 134.

3. See Richard Taylor, Metaphysics, 4th ed. (Englewood Cliffs, NJ: Prentice Hall, 1992), 53.

4. See Robert Kane, The Significance of Free Will (New York: Oxford University Press, 1998), 17. Hereafter, citations to this work will be abbreviated with $S F W$.

5. Robert Kane, "Responsibility, Luck, and Chance: Reflections on Free Will and Indeterminism," in Agency and Responsibility: Essays in the Metaphysics of Freedom, ed. Laura Waddell Ekstrom (Boulder, CO: Westview, 2001), 164.

6. "Anne" is the name Derk Pereboom gives her. See Pereboom, "Hard Incompatibilism," in John Martin Fischer, Robert Kane, Derk Pereboom, and Manuel Vargas, Four Views on Free Will (Oxford: Blackwell, 2007), 102. 
assaulted in an alley. Self-interest impels her toward the meeting, but compassion and a sense of responsibility impel her to help the person. For Kane, conflict experienced at the phenomenological level corresponds directly to competing neural networks at the neuronal level. Kane writes,

The two networks are connected, so that the indeterminism which made it uncertain that she would do the moral thing was coming from her desire to do the opposite, and vice versa .... When her effort to overcome self-interested desires succeeded, this corresponded to one of the neural pathways reaching an activation threshold, overcoming the indeterminism generated by the other. ${ }^{7}$

Thus, as Kane says elsewhere, "the indeterministic noise that is an obstacle to her making one of the choices is coming from her desire to make the other." ${ }^{8}$

Most discussions of KL have focused on its success or failure in rebutting the Luck Objection, the claim that indeterminism at the neuronal level seems to translate into luck and not moral responsibility. Kane puts the Luck Principle driving the Luck Objection thus: "(L) If an action is undetermined at a time $t$, then its happening rather than not happening at $t$ would be a matter of chance or luck, and so it could not be a free and responsible action." Responding to the Luck Objection has driven much of the literature on Kane's theory since its inception. ${ }^{10}$ The issue that concerns us here is different. We think that Kane's theory, which purports to rescue our intuition about how blame is inappropriate for fully determined actions, renders a sinless individual impossible. As we understand it, the kind of individual we are interested in remains sinless if she is not worthy of blame for particular faults and has made morally significant choices: choices some but not all of whose options are immoral. ${ }^{11} \mathrm{KL}$ is especially worthy of focus in this respect because the very things that are responsible for the indeterminism KL requires, namely, the neuronal networks, are themselves correlated to the moral struggles that a person encounters. The priority that an agent assigns a given network is supposed to be a function of how deeply she desires the action correlated with this network to occur. We argue that a sinless individual who makes morally significant choices cannot have the kind of moral conflict that Kane's theory requires, and thus his theory is vulnerable in this respect. In what follows, we develop our argument and consider two objections.

7. Kane, "Responsibility, Luck, and Chance," 165.

8. Kane, "Some Neglected Pathways in the Free Will Labyrinth," in The Oxford Handbook of Free Will, ed. Robert Kane (New York: Oxford University Press, 2002), 419.

9. See Kane, "Responsibility, Luck, and Chance," 158.

10. See, e.g., the December 2000 issue of The Journal of Ethics, in which Kane and Ishtiyaque Haji discuss the Luck Objection.

11. Let us adopt Alvin Plantinga's sense of "morally significant" here, where "an action is morally significant, for a given person, if it would be wrong for him to perform the action but right to refrain or vice versa." This, then, trades on Plantinga's further sense of being "significantly free" where our subject is "free with respect to a morally significant action." See Plantinga, God, Freedom, and Evil (Grand Rapids, MI: Eerdmans, 1974), 30. 


\section{Kanean Libertarianism Examined}

A central feature of the contemporary free will debate focuses on what Kane calls the "Compatibility Question," which asks whether free will is compatible with determinism. ${ }^{12}$ Almost all Compatibility Question discussions focus attention on the condition of alternate possibilities (AP), which serves as a preferred criterion for freedom. An agent satisfies this condition, and so is free, only if she could have done otherwise than she did at the very moment she did it. However in spite of its popularity, discussions of the Compatibility Question utilizing AP tend to stalemate. According to Kane, this just means that $\mathrm{AP}$ is an insufficient basis for incompatibilist arguments. KL thus proposes that a new criterion is needed in order to capture our intuitions about free will, including those that undergird AP.

Kane finds just such a criterion in his principle of Ultimate Responsibility (UR).$^{13}$ On that view, an agent is ultimately responsible only if she is, first, "responsible for anything that is a sufficient reason (condition, cause, or motive) for the occurrence of the action" (and so she is the ultimate source of the action). But, second, the choice she makes must be such that the action is "explicable in terms of the agent's purposes, efforts and reasons" (so that the action is genuinely intended and she is responsible for it). ${ }^{14}$ Under UR, the agent must be personally responsible not only for what she does, as in AP, but also for the sufficient causes and motives that explain why she acts in the way that she does.

The most significant feature of UR is its ultimacy condition (U), which requires that agents be responsible for the arche or sufficient reason for each free action that they undertake. By requiring control over the sufficient reasons for free actions, $U$ ensures that free actions cannot have sufficient reasons for which the agent is not responsible. However, $\mathrm{U}$ does not require that

12. Indeed it is not uncommon to see participants in the free will debate partitioned into camps determined by their answers to the Compatibility Question. Compatibilists claim that free will is compatible with determinism while incompatibilists deny this. While the literature on both views is extensive, noteworthy compatibilists include A. J. Ayer, "Freedom and Necessity," in Philosophical Essays, ed. Steven M. Cahn (New York: St. Martin's, 1954), 3-20; Harry Frankfurt, "Alternate Possibilities and Moral Responsibility," Journal of Philosophy 66 (1969): 829-39; David Lewis, "Are We Free to Break the Laws?," in Agency and Responsibility, ed. Laura Waddell Ekstrom (Boulder, CO: Westview, 2001), 30-7. Noteworthy incompatibilists include the earlier mentioned Roderick Chisholm, "Human Freedom and the Self"; Derk Pereboom, Living without Free Will (New York: Cambridge University Press, 2001); Peter van Inwagen, "The Incompatibility of Free Will and Determinism," Philosophical Studies 27 (1975): 185-99. See also Michael McKenna and Justin D. Coates, "Compatibilism," in Stanford Encyclopedia of Philosophy, ed. Edward N. Zalta, https://plato.stanford.edu/archives/win2016/ entries/compatibilism. Timothy O'Connor, "Free Will," in Stanford Encyclopedia of Philosophy, ed. Edward N. Zalta, https://plato.stanford.edu/archives/sum2016/entries/freewill.

13. Kane gives a full statement of UR at $S F W, 35$.

14. Kane, "Some Neglected Pathways in the Free Will Labyrinth," 407. See also Kane, "Two Kinds of Incompatibilism," Philosophy and Phenomenological Research 50 (1989): 232. 
the agent be the "complete or sole cause of the sufficient reason" but only that the agent, at some point in the past, made the indeterministic choice to render a reason either sufficient or insufficient for free action. ${ }^{15}$ Thus, factors about our genetic makeup, cultural predicament, and family history can have their say, but they do not utterly determine our actions. We make the choices (in at least some cases) about whether those factors will guide our actions or not.

Similarly, the responsibility condition (R) of UR does not require that the agent be directly responsible for every free action. In order to apply UR to finite agents, for whom an infinite regress is not possible, some free actions that are part of an agent's life history must be undetermined in the sense that they have no archai or causally necessitating reasons. These actions, called self-forming actions (hereafter SFAs), are nonetheless under the direct control of the agent, and are not necessitated (though they are brought about) by causes, conditions, or motives. The virtue of this account is that it preserves the intuition that our motivations are genuine causes for our actions without making them necessitating causes for them. ${ }^{16}$

In addition to being under the direct control of the agent, self-forming actions are will-setting in that by performing them the agent does not simply discover her priorities, but actually sets those priorities by choosing. Kane writes that the individual is faced with "motivationally viable options until the moment of choice or action and would set [her] will one way or the other by choosing or acting." ${ }^{17}$ Consider the earlier example of Anne, whose two motivationally viable options create a conflict between career and compassion. Each viable option would, if undertaken, be undertaken voluntarily in the sense that each is motivated by the agent's preexistent moral character, desires, and/or efforts. In addition, the agent has reasons and motivations that support each viable alternative. By acting and so choosing which among the motivationally viable options is enacted, the agent sets her will and so alters the moral character from which future actions will be decided upon.

Anne, in exercising full indeterministic control over her decision, say, to help the victim in the alley, could thereby set her will in such a decisive way as to make similar future voluntary refrainings from helping effectively impossible, without compromising her ultimate moral responsibility for those future actions. ${ }^{18}$ This will-setting feature of SFAs allows free agents to fash-

15. Kane, $S F W, 74$.

16. For a discussion of how causes can be nonnecessitating, see Elizabeth Anscombe, "Causality and Determination," in Agency and Responsibility, ed. Ekstrom, 57-73.

17. Kane, "Some Neglected Pathways in the Free Will Labyrinth," 412.

18. An objector might wonder whether Anne is also endorsing this curtailment of her future options. In this context, Kane discusses Martin Luther's famous claim at the Diet of Worms that "Here I stand, I can do no other." He writes, "Luther's 'Here I stand' would have been an affirmation for which he was ultimately responsible, even if it was determined and even if he could not have done otherwise, so long as it was a willed action (issuing from his character and motives) and he was responsible (as $U$ requires) by earlier undetermined SFAs for the character and motives from which the affirmation issued" $(S F W, 77)$. 
ion their own wills and so to have direct responsibility for and control over their moral character and motivations. As a result, agents can be derivatively responsible for actions that are not self-forming and so are necessitated by their archai so long as these archai originate from self-forming actions.

Kane would have us imagine that Anne's indeterministic choice is a complex process in her brain composed of neural networks that are chaotic and so sensitive to small changes at the quantum level. Kane claims that "persons experience these complex processes phenomenologically as 'efforts of will' they are making to resist temptation in moral and prudential situations." ${ }^{\prime 19}$ At this point, a reader might be inclined to think that this choice represents an uncaused action, rather than a properly self-caused, voluntary action of an agent. ${ }^{20}$ However, Kane responds that the indeterminacy in one neural network, such as the one corresponding to Anne's potential decision to help the man being assaulted, is generated by conflict with a competing neural network, such as the one corresponding to Anne's effort to make it to the meeting, and does not have a source outside of the agent. In an SFA, the agent cannot bring an effort to fruition without first overcoming the indeterminism caused by competing efforts. The system of these competing efforts and motivations, represented by neural networks, helps to constitute the self, or what Kane calls the "self-network." ${ }^{21}$ The case, says Kane, is less like the rolling of a die to decide what one's action will be, and more like concentrating on a mathematical problem, for whose solution the agent is responsible, in the face of the "indeterministic noise" of other competing motivations one may have. ${ }^{22}$

\section{A Problem for Kanean Christians}

What is clear about Kane's account at this point is that there will be what Elizabeth Anscombe calls necessitating causes and nonnecessitating causes at various points in the motivational structure of the agent. ${ }^{23}$ The nonnecessitating causes will be those efforts of will that win out in indeterministic decisions that Kane calls SFAs. The necessitating causes will be archai, or sufficient reasons for actions that will have resulted from some prior set of indeterministic SFAs. But in this context a problem for the initial SFA itself comes into view.

19. Kane, $S F W, 130$.

20. Richard Taylor differentiates the causation of determinism with what he calls simple indeterminism (which holds that some events are uncaused), and then claims that free actions must be self-caused. See Taylor, Metaphysics, 33-53.

21. Kane, $S F W, 139$.

22. For a fuller response to the so-called Luck Objection, see Kane, "Responsibility, Luck, and Chance."

23. See Anscombe, "Causality and Determination," 69. 
To see this, consider a case furnished by a scene in C. S. Lewis's novel Perelandra ${ }^{24}$ an episode that Kane himself discusses in his early book Free Will and Values. ${ }^{25}$ Lewis's character, Ransom, upon visiting the planet Perelandra (Venus), meets a human-like creature whom he learns has been commanded by her God never to leave the floating islands that partially cover her world for fixed land. Ransom tells this creature that everyone in his world lives on fixed land, unintentionally tempting her to disobey her God. As Kane says, "such knowledge brings an end to moral innocence." ${ }^{26} \mathrm{He}$ further notes Ransom's realization that "they are reenacting the Garden of Eden scene between Eve and the serpent, and he is playing the serpent." ${ }^{27}$

It is here where our question can come into view. Is this Eve character (who remains unnamed) experiencing a morally significant struggle? If not, then Kane's theory would not be able to purchase incompatibilist freedom in this type of action (seemingly a paradigm case for an SFA). On KL, the needed indeterminism is caused by competing neural networks that the agent experiences phenomenologically as moral struggle. On the other hand, if the Eve character does experience moral struggle, then we need to ask some difficult questions about her motivational structure (and here we depart from the text of Lewis's case for the sake of simplicity). Supposing that she bears all the relevant similarities to human moral agents, she will need neurological indeterminacy together with conflicted desires about which course of action to pursue. Now, if this conflict is again morally significant, one pathway will represent a morally blameworthy choice, and another will represent a morally praiseworthy choice. ${ }^{28}$ But all the while she will be attempting to bring about both choices. ${ }^{29}$

24. C. S. Lewis, Perelandra (New York: Scribner, 1972), 63-5.

25. Robert Kane, Free Will and Values (Albany: SUNY Press, 1985), 202.

26. Ibid., 203.

27. Ibid., 202.

28. We choose "morally blameworthy" and "morally praiseworthy" instead of a "morally inferior choice" and a "morally superior choice" here. Some have objected to us that it does not follow uncontroversially from the fact that an agent could have been better that the agent acted sinfully. Perhaps. But either the choice that is made makes the agent sinful or it doesn't. If neither choice would have made the agent sinful, then the option does not seem to have the requisite moral significance, since somehow an agent will have to confront choices that could render her sinful, and those are the ones that concern us. If, on the other hand, one of the courses of action makes one sinful, and the other does not, then the case is exactly the one that concerns us, and the objection is moot. Kane notes that "in moral cases, the incommensurable reason sets are motives of duty versus self-interest" $(S F W, 167)$. The reasons are incommensurable prior to the SFA because to make them commensurable would be to assign them a motivational priority in advance, and thus determine the victor of the moral struggle. The point is that they are not commensurable yet.

29. The length (in terms of temporal duration) of the struggle is not relevant to our question, although it's certainly easier to imagine a prolonged struggle being one that reflects poorly on an agent's moral priorities. Nevertheless, we are not committed to a particular way of representing the struggle. All our argument requires is that Kane's account sees the indeterministic noise that makes an SFA possible as one that results from the dual tryings of the agent. 
There is, perhaps, something counterintuitive about the idea that an agent is at the same time attempting to bring about both choices. It seems not to be rational, for example, to try to make two obviously incompatible choices at the same time. Furthermore, if trying to make a choice is an active effort, then it must be a free effort or its outcome will not be a free choice. KL would then also require an account of freedom concerning these efforts of will that contribute to an SFA. ${ }^{30}$ Objections like these, which threaten the very idea of SFAs, are independent of ours. However, they are mutually reinforcing: each suggests that SFAs are problematic, particularly when no prior free choices influence the efforts of will that precede them.

Indeed, our commonplace intuitions would seem to have it that some moral conflicts are more severe than others, and that the severity of an individual's moral conflict is correlated with our moral assessment of the agent, since sin in the interior of an agent is possible. For example, in Woody Allen's 1989 movie Crimes and Misdemeanors, Judah Rosenthal agonizes over whether to have his mistress killed. Her disclosure of their affair would damage his family and career. As we watch the movie, we can imagine it going either way (he actually does have her killed). But someone who briefly entertains a murder as a serious and potential course of action and then willfully puts it out of her head would seem less blameworthy than Judah Rosenthal. Even if he had not committed it, Rosenthal struggles at length with the murder as a real course of action. Thus, we would consider an agent with a short-lived - though sustained-impulse to, say, commit a heinous murder to be morally less blameworthy (though still blameworthy) than an agent who goes through a long, paralyzing struggle about whether to commit one (absent any psychological abnormalities). ${ }^{31}$ But that way of putting the issue just reinforces the point. In Kane's theory, self-interest and duty are making the indeterministic noise that makes the other choice difficult, and Kane understands them as efforts of will. Without the will supporting both paths, there would actually be no struggle because there would only be one effort of will, rather than two, and none of the needed indeterminism for an SFA. Thus, on Kane's theory, it would be impossible to undergo a morally significant

30. For examples of this sort of worry, see Randolph Clarke, "Libertarian Views: Critical Survey of Noncausal and Event-Causal Accounts of Free Agency," in The Oxford Handbook of Free Will, ed. Robert Kane (New York: Oxford University Press, 2002), 356-85; Clarke, "Freedom of the Will," in The Blackwell Guide to Philosophy of Mind, ed. Stephen P. Stich and Ted A. Warfield (Oxford: Blackwell, 2003), 369-404; Mele, Free Will and Luck (New York: Oxford University Press, 2006). Kane addresses some of these worries in his "Response to Fischer, Pereboom, and Vargas," in John Martin Fischer, Robert Kane, Derk Pereboom, and Manuel Vargas, Four Views on Free Will, (Oxford: Blackwell, 2007), 166-83.

31. Kane's usual example of Anne the businesswoman is not deliberating about an action that is morally heinous in itself (attending the meeting over against helping the man on the street), but it is part of the example that her attending the meeting is morally blameworthy in context, and that is all that we need. 
struggle and yet have the agent emerge morally unscathed, ${ }^{32}$ because the requisite indeterminism would come from the conflict between an effort of will to do something morally blameworthy and an effort of will to do something morally praiseworthy.

An objector might reject our claim that the severity of a struggle is correlated with our moral evaluation of the agent. She might argue that, since some struggle is necessary for freedom, one can't blame the agent for the existence of the struggle. In response, it must, of course, be conceded that a garden variety moral agent who is purely instinctually drawn toward a lesser good can hardly be blamed for the mere existence of the struggle. The problem is not with the existence or even the duration of the struggle as such but with its source in the agent's voluntary efforts of will. Indeed, instinctual attraction to a lesser good seems to us to be what is going on in the case of Jesus's struggle at Gethsemane (Luke 22:39-46). Jesus has an instinctual desire to avoid a gruesome death; he does not make a volitional effort to nurture the anguish involved in proceeding to it. Jesus therefore can be said to experience emotional turmoil although Jesus does not voluntarily intend the struggle he undergoes itself. ${ }^{33}$ This is why, in the epigraph to this paper, Saint Francis de Sales distinguishes between "the fine point of [Christ's] spirit" and the "struggle of nature." ${ }^{34}$ However, when it is claimed that the struggle, in order to be genuine, must have agential efforts of will on both sides of the conflict, then we think a Christian should part ways with Kane. For our objection is with Kane's rendering of common sense, not common sense itself. We agree that an agent should not be blamed for the existence of a moral struggle per $s e$, but that agreement does not mean that Kane's view of moral struggle is the right one.

For Kane's theory holds that libertarianism requires indeterminism at the neuronal level with which agential efforts are phenomenologically identical. ${ }^{35}$ This means, as Kane himself says, that agents' "resistance or impediment to their efforts to act morally and prudentially is coming from their own wills. ${ }^{"}{ }^{6}$ Kane goes on to write, "Whatever the agents may consciously be-

32. As noted earlier, though, the theory could perhaps persist as a non-Christian theory that held complete sinlessness in moral agents who experience morally significant choices to be a merely regulative ideal.

33. It has been suggested to us that if a Christian accepted our thesis and consequently held that sin is a necessary condition of moral agency for Kane's view, then perhaps she would simply believe that Jesus's agency was somehow beyond the relevant kind of moral agency. We are not persuaded that this will do justice to Jesus's human nature (especially since it seems to flirt with the heresy of monothelitism), though it is worth noting that even if one were to produce a defensible theory of the Incarnation and atonement on this supposition, then one of us would be quite happy to refigure this article as an argument for why Catholics should not be Kaneans, in accordance with Catholic teaching on the Virgin Mary.

34. See St. Francis de Sales, The Art of Loving God: Simple Virtues for the Christian Life (Manchester, NH: Sophia Institute Press, 1998), 44-5.

35. See Kane, $S F W, 130-2$.

36. Ibid., 132 (emphasis in original). 
lieve or avow about the priority of moral or prudential reasons, the fact is that if we look more deeply into their full psychological profiles ... there is some doubt and indecision in their minds about this priority. If not, there would be no genuine conflict. ${ }^{.37}$ But here again is the problem: If moral confusion (that is, "doubt" or "indecision" about one's moral priorities, and not one's set of moral information) is a necessary condition for genuine moral struggle and the latter is a necessary condition for morally significant incompatibilist free action, then it follows that all human moral agents who make or have made a morally significant choice are at some time of two minds about what they should do. Here Neil Levy's related charge against Kane's theory sinks in: "Dual control and dual rationality leads to dual responsibility: responsibility for what we do, and for what we would have done instead." ${ }^{38}$ Note also that Kane himself says that agents in this sort of state are "of two minds." 39 It does not seem to us an accident that James 4:8 reads "Cleanse your hands, you sinners, and purify your hearts, you of two minds." ${ }^{40}$

Indeterminism in the brain (when the brain is in the right sort of chaotic state) entails conflict in the agent, but conflict in the agent entails competing efforts of will to bring the competing courses of action to fruition. What of these competing efforts of will? Kane would no doubt claim that they are not yet full intentions, but is he allowed this claim? Certainly, if the efforts of will that generate the conflict are purely instinctual, then their bare existence cannot be blamed on the agent (that would seem to be Saint Francis's "struggle of nature"). But do the efforts of will come with a predetermined strength, so that one desire has a strength of ninety and one a strength of ten? Of course not; if they did, the priorities of the desires would already be assigned and then the victor of the struggle would already be predetermined. The strength of the efforts of will is determined by the agent, and in the course of the willsetting that is an SFA. ${ }^{41}$ And this must be true so that Kane can escape the Luck Objection. ${ }^{42}$ It is a matter of the agent's effort, and not chance, that the course of action chosen actually wins out.

Nor will it do to argue that to desire an action requires only that a person desire an aspect of it, so a person might desire another bowl of pudding even if eating it on this occasion would be gluttonous. It is obviously the case that agents are not blameworthy for being attracted to an action under a desirable aspect of it as long as they are not genuinely in agential turmoil over whether

37. Ibid.

38. See Neil Levy, "Contrastive Explanations: A Dilemma for Libertarians," Dialectica 59 (2005): 53.

39. See Kane, "Responsibility, Luck, and Chance," 170.

40. Citations are from the New American Bible, revised edition.

41. Alfred Mele calls this the plasticity of moral motivation and discusses it at length in the fourth chapter of his book Springs of Action (New York: Oxford University Press, 1992).

42. Again, if the strength that an agent gives the desires in the course of the SFA itself does not determine the victor of the struggle, then the victor of the struggle will not reflect the agent's wishes, and thus will have been a matter of chance or luck. 
to choose a morally blameworthy action itself. The trouble is that neuronal networks for Kane correspond to full courses of action and not just aspects of them. If these were only aspects of actions, then the winning out of one of the networks would inadequately explain the action itself, since on Kane's theory the indeterminism requisite for freedom in SFAs is generated by the agent trying to perform each of the conflicting actions, and not merely by being attracted to one aspect of each of them. As Kane writes in his businesswoman example, "she will have succeeded in doing what she was trying to do. And the interesting thing is that this will be true of her, whichever choice is made, because she was trying to make both choices and one is going to succeed." ${ }^{\prime 3}$

Thus, consider a situation where one encounters a person on the side of the road who is in dire need of assistance while driving to one's son's baseball game, even as the first pitch is approaching. Now suppose that one promised to make it to the game in time for the first pitch, and that the need of the stranger is so dire that not providing assistance would constitute a moral fault, even in the face of the countervailing promise. If one struggles morally over this decision, what is the struggle between? Surely it can't be between one's inclination to keep $a$ promise and one's inclination to provide some assistance to a stranger (which are both morally praiseworthy aspects of each action). Such struggles are too vague to be morally significant, even if the agent were happily to alight on those features rather than some other set of features. Rather, the struggle needs to be between keeping this promise of this gravity as compared with this person in this situation who needs this sort of assistance. Only that kind of struggle will genuinely form the moral self of the person in question, as self-forming actions must. But these latter descriptions of the choice are too thick to be simply aspects of an action; rather, they constitute the action in its morally relevant features.

It is a fair point that the dual efforts of will Kane espouses here, such that our agent's choice, or Anne's choice, is the result of really trying to make both decisions at once, reflects a modification of Kane's original view, which appears to be part of his attempt to respond to the Luck Objection. ${ }^{44}$ Indeed, one dilemma for Kane here, as Randolph Clarke notes ${ }^{45}$ is that holding that the efforts of will are undetermined by the agent is just succumbing to the Luck Objection, but holding that the efforts of will that result in a decision are themselves determined by the agent threatens a regress of responsibility. Thus, at this point, one might argue that Kane's theory is simply incoherent, since, if an SFA is to bring an agent's will into being, then it makes no sense to appeal to dual agential tryings that exist prior to the agent's decision. We are agnostic about whether Kane's theory can respond to this challenge suc-

43. See Kane, "Responsibility, Luck, and Chance," 170.

44. See Randolph Clarke, "Incompatibilist (Nondeterministic) Theories of Free Will," in Stanford Encyclopedia of Philosophy, ed. Edward N. Zalta, http://plato.stanford.edu/cgi-bin/encyclopedia/archinfo.cgi?entry=incompatibilism-theories, esp. sec. 2.3.

45. Ibid. 
cessfully. If he is successful, it will have to be by assigning agential control to both of the dual efforts of willing. But even if Kane can respond to Clarke's regress challenge, we still think that a sinless individual (who makes morally significant choices) is impossible on that account.

Our objection to Kane's theory can be put simply, however misleadingly, as follows: since both competing efforts of will in a morally significant decision are the work of the agent, the agent is in effect playing chess with herself. She knows in advance that she will win, but she does not know whether she will represent the white side or the black side. But why is she doing this with her moral character? Admittedly, the analogy breaks down because in a game of chess, as in a game of baseball, one can advance one's queen while knowing that the knight will take it later; one can throw the game. But here the agent cannot even know the priorities that she will assign to each of the competing efforts, or else the struggle is already preempted. A genuine moral struggle, for Kane, entails the voluntary, and not just instinctual, valuing, however slight, of a morally blameworthy course of action. To boil the argument down to a dilemma: in a context of a morally significant indeterministic choice, Kane must either hold that conflicting desires acquire their priorities through the willing of the agent or claim that they do not. If the former, the agent cannot be sinless. If, on the other hand, immoral desires acquire their priorities through other factors such as instinct, succumbing to or resisting the immoral desire cannot be genuinely voluntary. This is certainly a dilemma, but since both options are likely to be unsatisfactory to a great number of (incompatibilist) Christian theists, we think that $\mathrm{KL}$ is problematic for them.

\section{Some Further Objections}

We have argued that Kane's theory of libertarian freedom cannot support the existence of a sinless individual who faces a morally significant choice. This should be troubling to Christian theists who hold that (at least) one human being was in fact sinless. Yet, we believe that the theory is unable to support this element of Christian orthodoxy because it must hold that the valuing of the desires that generate moral struggle (which in turn is a necessary condition for libertarian freedom on KL) is the voluntary work of the agent, and a sinless agent cannot voluntarily accord value to an immoral desire. In this section, we will respond to two remaining objections that we anticipate to our argument.

\section{Objection 1}

It's perfectly ordinary for an agent to be in a conflict between one instinctual motive and another moral motive. But Kane's theory can make sense of this, since the winning out of the moral motive is just the victory of free will over animal instinct. It is simply autonomy winning out over heteronomy. So, 
when a sinless individual confronts such a situation, she summarily closes off the pathway to the action dictated by instinct. If she does this in such a summary fashion, then her character cannot be impugned because of it, and she retains her spotless moral standing.

\section{Response}

As we have already acknowledged, free agents are not blameworthy for their instincts insofar as they are outside of the agent's control. However, there is a distinction between having an instinct and being of two minds with respect to the course of action dictated by instinct. Accordingly, Objection 1 treats the instinct as if its priority were already assigned. But it is not; it is the agent's job to determine the priority of each viable option in the context of this intra-agent struggle. If this priority were not assigned by the agent, then the action would be predetermined by external factors and so not free in the sense of UR. ${ }^{46}$

\section{Objection 2}

Suppose we try a different strategy. Suppose that we concede that one type of theoretically "spotless" agent is not a possibility. However, we may be able to rescue the moral-phenomenological character and experience of the sinless moral agent. As much as we Kaneans need to insist that there is a one-to-one correspondence between neurological events in the self-network and the phenomenology of the agent, some neurological events may be too minute to make a phenomenological dent. Neurologically, the agent may asymptotically approach, and never quite reach, theoretical sinlessness. But perhaps an agent is so morally sturdy as to have this neurological struggle never make a practical difference. In this case, we can retain everything we need to about a sinless agent.

\section{Response}

Two problems arise with this objection. In practically sinless agents, by hypothesis, this neurological conflict in some SFAs is too minute to make a phenomenological dent and so does not make a practical difference in our moral evaluation of the agent. But how are these minute neurological conflicts possible? Kane argues that in SFA scenarios the brain moves out of thermodynamic equilibrium and into a chaotic state. As a chaotic system, the brain exhibits sensitive dependence on initial conditions so that small

46. One possible exception to this is if the predetermined strength of two options is perfectly equal. But in this case the result is not an SFA but paralyzing indecision and angst (and, perhaps, moral blameworthiness for a sin of omission). If the predetermined strength were not perfectly equal but only equal enough (in some unspecified way), then the result of this might be a chaotic state that would need to be resolved by a decision. If this new decision were again free, there would be indeterminism and so an SFA situation would be produced. But in this case, as in other genuine SFA situations, the agent assigns priorities by acting and so chooses which outcome to actualize. If this is not the case, then the agent is back in a situation of luck. If it is the case, then everything we say still applies. 
changes on the quantum level are amplified and so manifested on the neurological level. Objection 2 claims that small changes can be made to this system without producing large scale effects. Yet, the impact of such changes is impossible to predict in these chaotic systems. Any change will become amplified over time and so the small changes that the objector requires will (or at minimum may) quickly become big changes. So, at best, the loss of correspondence between phenomenology and neurology accepts some significant aspect of agential luck.

Perhaps more importantly for this paper, though, neurological conflicts do often make a phenomenological dent in sinless beings. For example, Jesus's struggle in Gethsemane is certainly not a small one. Luke 22:44 tells us that "[Jesus] was in such agony and he prayed so fervently that his sweat became like drops of blood falling on the ground." This clearly does make a phenomenological dent, and so the objector's strategy does not do justice to this paradigm case. Kane's theory would hardly be very attractive if it could only explain moral struggles that are phenomenologically undetectable to the agent and to others, but that is the concession that would be required if the struggle is supposed to be only neurological and not phenomenological. Moreover, at the theoretical level, if there is only a loose connection between the neurological and phenomenological spheres, then Kane's theory loses much of its appeal to metaphysicians. If the chaotic brain state required by KL obtains but without the requisite struggle then KL appears to endorse a kind of dualism between mind and body and to become the very kind of agent-causal account that it was trying to avoid. ${ }^{47}$

\section{Conclusion}

Our argument in this paper is that Kane's theory of libertarian freedom cannot accommodate the existence of a sinless individual, because a sinless agent cannot voluntarily accord value to an immoral desire. We maintain that this is problematic for Christians, for whom the heavy weight of tradition holds that Jesus of Nazareth is sinless. There are, of course, some free actions that are not morally charged. For example, Kane's widely referenced example of Jane's undetermined decision to fly to Hawaii or Colorado for vacation seems to be one such case. If Jane struggles with whether to fly to Hawaii or Colorado, we do not necessarily say that her valuing of Colorado is morally suspect even if she should later choose Hawaii ${ }^{48}$ But with morally significant decisions (presumably the kind of decisions with respect to which one wants freedom), an agent cannot voluntarily accord value to a course of action that is morally blameworthy and retain her sinlessness. In the case of SFAs that

47. This, however, is not to say that we agree with all such objections to agent causal theories. 48. Kane, "Responsibility, Luck, and Chance," 161. 
are morally significant, we have argued that this is unavoidable for Kaneans, and this is why we think that Christians should not endorse this theory. ${ }^{49}$

49. Our thanks to anonymous reviewers, Nick Perovich, and to Betty Talbert for helpful advice on this paper. 